\title{
Occupational status as a determinant of mental health inequities in French young people: is fairness needed? Results of a cross-sectional multicentre observational survey
}

Marie Blanquet ${ }^{1,2^{*}}$, Emilie Labbe-Lobertreau ${ }^{3}$, Catherine Sass ${ }^{3}$, Dominique Berger ${ }^{4}$ and Laurent Gerbaud ${ }^{1,2}$

\begin{abstract}
Background: Employment conditions are associated with health inequities. In 2013, French young people had the highest unemployment rate and among those who worked as salaried workers most of them had temporary job. The purpose of the study was to assess mental health state of French young people through the prism of their occupational status and to measure whether occupational status is a determinant of health inequities.

Methods: A cross-sectional multicentre observational survey was performed in June and July 2010 in 115 French Local Social Centres and 74 Health Examination Centres, who were available to participate. The survey was based on an anonymous self-administrated questionnaire delivered by social workers or healthcare professionals to young people age from 16 to 25 years old. The questionnaire was composed of 54 items. Several health outcomes were measured: self-perceived health, mental health, addictions and to be victim of violence. The association of occupational status and mental health was assessed by adjusting results on age and gender and by introducing other explanatory variables such as social deprivation.
\end{abstract}

Results: A total of 4282 young people completed the questionnaire, a response rate of 83\%, 1866 men and 2378 women, sex-ratio 0.79 . French young people having a non-working occupational status or a non-permanent working status were more exposed to poor self-perceived health, poor mental health, addictions and violence. To be at school particularly secondary school was a protective factor for addiction.

Conclusions: Occupational status of French young people was a determinant of mental health inequities. Young people not at work and not studying reported greater vulnerability and should be targeted therefore by appropriate and specific social and medical services.

Keywords: Health inequities, Occupational status, Young people, Self-perceived health, Mental health

\footnotetext{
* Correspondence: mblanquet@chu-clermontferrand.fr

'Service de Santé Publique, Centre Hospitalier Universitaire de

Clermont-Ferrand, 7, place Henri Dunant CEDEX 1, 63058 Clermont-Ferrand,

France

${ }^{2}$ Clermont Université, Université d'Auvergne, EA 4681, PEPRADE (Périnatalité,

grossesse, Environnement, PRAtiques médicales et DEveloppement),

Clermont-Ferrand, France

Full list of author information is available at the end of the article
} 


\section{Background}

The World Health Organization-Europe (WHO) has defined social inequities in health as "systematic differences in health status between socioeconomic groups, as measured by income, education and occupation that are, within a country, socially produced, modifiable and unfair" [1]. As there are determinants of health defined by factors that influence health positively or negatively, there are also determinants related to social, economic and life-style conditions that play a role in health status. They are conceptualized by macro and micro-conceptual frameworks $[1,2]$. The micro-conceptual framework depicted influence employment conditions on health inequities through working conditions, material deprivation and economic inequities and psychosocial factors [3]. The relationship between employment, working conditions, and adverse health outcomes, low self-perceived health [4-8], bad and poor physical health [8-11], and mental health [9-13], have been previously explored by several studies.

The concept of deprivation was both defined by Wrezinski as "the lack of safety, like a job, enabling individuals and families to assume professional, family and social responsibilities and to enjoy basic rights" and by Townsend as a "state of observable and demonstrable disadvantage relative to the local community or the wider society to which an individual, family or group belongs" and identified as the main cause of inequities in health $[14,15]$. As a continuum, precarious employment might be defined as "a multidimensional construct encompassing dimensions such as employment insecurity, individualized bargaining relations between workers and employers, low wages and economic deprivation, limited workplace rights and social protection, and powerlessness to exercise workplace rights" [16]. Even if no consensus exists on its definition, precarious employment appears to be an emerging social determinant of health that Benach et al. put at a central place in their conceptual model with straight influence on hazardous working conditions, material deprivation, and health and quality of life. This central place warrants the needs of further research [16].

The most recent French study on labour market made by the National Institute of Statistics and Economic studies (Insee), in accordance with the International Labour Organization (ILO) definitions, was performed in 2013. This survey, based on data recorded in 2013, showed highest unemployment rate in young people aged $15-24$ years old, $23.9 \%$ vs. $9.1 \%$ in the $25-49$ year old group and $6.5 \%$ in people aged 50 years old or over with an annual average unemployment rate of 9.8\% [17]. Young people had also the highest underemployment rate $11.7 \%$ vs. $6.2 \%$ in the $25-49$ year old group and $5.7 \%$ in person aged 50 years old or over [17]. They worked as salaried workers more frequently than the economically active population (97.5\% vs. $88.8 \%)$ with greater proportion of young people working in interim $(5.9 \%$ vs. $2.0 \%)$, in training school $(18.1 \%$ vs. $1.6 \%)$ and in temporary job ( $28.3 \%$ vs. $8.4 \%)$ [17].

Taking into consideration this context, the National Council of Local Social Centres (Conseil National des Missions Locales- CNML), who has the mission to understand and improve integration of young people into the work place mechanisms, asked the Support and Education Technical Centre of Health Examination Centres (Centre technique d'appui et de formation des centres d'examens de santé-CETAF), for a survey on young people's health through their occupational status.

The main aim of our survey was to assess mental health state of French young people through the prism of their occupational status. The secondary aim was to measure whether occupational status of French young people is a determinant of health inequities. Specifically, self-perceived health, mental health, addictions and violence were assessed by adjusting results on sociodemographic variables and by considering childhood major event, social support, and health care consumption.

\section{Methods}

\section{Setting}

In France, 447 Local Social Centres (LSC), created in 1982 (Order n82-273, March 1982), provide social, health and education support to young people without qualification, to be integrated into the workplace. Since its creation, 1,400,000 of young people were taken in each year. There also are 112 preventive Health Examination Centres (HEC), created in 1945 (Article L321-3 Health insurance Code). They provide preventive medical consultations to beneficiaries of the national health insurance for salaried workers and their family. Patients do not pay and can consult without being referred. In 1992, a ministerial order designated who should have priority for these consultations, such as retirees, job seekers, young people just entering the job market, the homeless and people exposed to risk factors for health [18]. These people account for a third of all those annually cared for by the HECs.

\section{Methods}

A cross-sectional multicentre observational survey was performed in June and July 2010 in 115 French LSC and 74 HEC. LSC and HEC were free to participate.

The survey was based on an anonymous selfadministrated questionnaire delivered by social workers or healthcare professionals working in the LSC or HEC. Professionals explained to young people the aim of the survey and were available to answer questions young people could have. The survey was carried out during 2 weeks per LSC or HEC. 
The questionnaire was elaborated by a working group between 2007 and 2008. The working group was composed by the CNML, the French national health insurance for salaried workers (Caisse Nationale d'Assurance Maladie-travailleurs salariés- CNAMts), Health Directorate (Direction Générale de la Santé-DGS), Social Welfare Directorate (Direction Générale de l'Action Sociale- DGAS), the CETAF and representatives of LSC and HEC. A first version of 68 items has been elaborated based on questionnaires previously used in the European School Survey Project on Alcohol and Other Drugs (ESPAD), the French Health Barometer and the survey of the French Monitoring Centre for Drugs and Drug Addiction (Observatoire Français des drogues et des Toxicomanies-OFDT). The first version was tested in 24 LCS and 14 HEC on 1342 questionnaires. The second version was then elaborated and used in the present work.

\section{Population}

People included were young people age from 16 to 25 , coming from LSC or HEC. There were no exclusion criteria. The first 15 to 30 people who were taken in charge by social workers in LSC and health care professionals in HEC were asked to participate in the study. All participants gave their informed consent to be enrolled.

\section{Questionnaire}

The questionnaire was composed by 54 items on socio-demographic status, deprivation, addictions, psychological disorders, health state, violent behaviour and discrimination and the need of medical, social or family support. The socio-demographic status included 21 items: age, sex, home location, own and parent's current occupational status, level of education, social support, medical insurance, and serious childhood life events. Details on young people' occupational status, are displayed in the Additional file 1. Deprivation was measured by the EPICES score, a validated individual score of individual social deprivation $[19,20]$. Addictions included items about alcohol; consumption in the last 30 days and drunkenness in the last 12 months, current tobacco consumption and marijuana consumption in the last 30 days and feeling of need to smoke marijuana to feel health since the morning. Life events during childhood were measured by 4 items: have lived family events as break-up, disease, depression, alcoholism etc.; have had accident or serious illness; have been involved in an educative or judicial intervention; how was the childhood and adolescence. Psychological disorders were measured by two validated questionnaires, the Mental Health Index (MHI-5) and the Adolescent Depression Rating Scale (ADRS), and by items about suicide [21]. Health state was also measured by the scale of self-perceived health. Three kinds of violence behaviour, psychological, physical and sexual, as victim or perpetrator were assessed. Discrimination in different place (employment, accommodation, leisure, education and transports) was also integrated into the questionnaire. Then, people were questioned about needs for medical, social or family support they had had during the past 12 months (Additional file 2).

\section{Health outcomes}

Nine health outcomes were measured: self-perceived health, mental health, addiction and to be victim of violence. Self-perceived health was a validated and relevant measurement of health predicting mortality [22, 23]. It was measured through a numeric scale from 0 for the poorest self-perceived health to 10 for the best selfperceived health. The threshold of 7 was used with poor self-perceived health under 7 [24, 25]. Mental health was assessed by the Mental Health Inventory- 5, a dimension of the well-known and validated SF-36, with psychological distress under 56 and a question about suicide attempt. Addiction to three substances was measured: current tobacco use, alcohol misuse (when young people reported being drunk at least three times in the last year) and marijuana use. Exposition to three kind of violence was explored, psychological, physical and sexual violence.

\section{Explanatory variables}

The main explanatory variable assessed, as in occupational status of French young people, was composed by 13 categories: permanent job, temporary job, interim, specific employment contract, to be at school or secondary school, to study at university or out of university, training school, to be in block release training school, trainee in education, in integrating into the work place, job seeking or unemployed. The other explanatory variables were level of education (low when <2nd school diploma and high when $>2$ nd school diploma), major event in childhood (meaning yes if the person reported at least one kind of major event during his childhood), deprivation (through the calculation of EPICES score), discrimination (i.e.-if the person declared being victim of at least one kind of discrimination), financial social support (i.e.-if the person received at least one kind of financial support), social worker support (if the person met a social worker during the last 12 months), social network support (if the person met family, friends or other relations in the last 12 months), and health care consumption (meaning the person met a health care professional in the last 12 months). 


\section{Statistical analysis}

Descriptive analysis was performed to assess the sample characteristics by using percentage for qualitative variables and means with standard deviation for quantitative variables. Multivariate analysis was performed by using stepwise forward logistic regression adjusted on age and gender to assess health outcomes through three steps. The first step integrated the occupational status as explanatory variables adjusted on age and gender. The second step added all the other explanatory variables, excepting individual social deprivation measured by the EPICES score. The third step added all the explanatory variables statistically significant at the second step and the EPICES score, to identify information this explanatory variable specifically brought into the model. Logistic regression models identified meaningful explanatory

Table 1 Descriptive analysis in the whole sample and comparisons by gender

\begin{tabular}{|c|c|c|c|c|}
\hline & $\begin{array}{l}\%^{\mathrm{a}} \mathrm{m}^{\mathrm{b}}[\mathrm{sd}]^{\mathrm{c}}\left(\mathrm{n}^{d}\right) \\
\text { Total; } N=4282\end{array}$ & $\begin{array}{l}\%^{\mathrm{a}} \mathrm{m}^{\mathrm{b}}[\mathrm{sd}]^{c}\left(n^{d}\right) \\
\text { Men; } N=1866\end{array}$ & $\begin{array}{l}\%^{a} m^{b}[s d]^{c}\left(n^{d}\right) \\
\text { Women; } N=2378\end{array}$ & $p$-value \\
\hline Age & $20.91[2.59](4235)$ & $20.75[2.63](1860)$ & $21.03[2.54](2375)$ & $<0.001$ \\
\hline Level of education (low) ${ }^{e}$ & $68.6(4188)$ & $74.4(1822)$ & $64.0(2329)$ & $<0.001$ \\
\hline Occupational status & $(4212)$ & $(1850)$ & $(2360)$ & $<0.001$ \\
\hline Permanent job & 6.0 & 5.7 & 6.2 & \\
\hline Temporary job & 4.7 & 3.8 & 5.3 & \\
\hline Interim & 3.4 & 5.4 & 1.9 & \\
\hline Specific employment contract & 2.7 & 2.1 & 3.2 & \\
\hline School/secondary school & 8.8 & 8.5 & 9.0 & \\
\hline At university & 3.5 & 2.9 & 4.0 & \\
\hline Out of university & 3.0 & 1.5 & 4.2 & \\
\hline Training school & 2.5 & 4.1 & 1.4 & \\
\hline Block release training school & 4.0 & 4.5 & 3.5 & \\
\hline Trainee in education & 10.9 & 10.5 & 11.2 & \\
\hline In integrating into the work place & 5.7 & 7.1 & 4.5 & \\
\hline Job seeking & 36.3 & 35.4 & 37.1 & \\
\hline Unemployed & 8.5 & 8.6 & 8.5 & \\
\hline Major event in childhood (yes) & $61.5(4253)$ & $62.5(1849)$ & $60.6(2368)$ & $n s^{h}$ \\
\hline EPICES score quantitative & $40.17[20.34](3791)$ & $40.29[19.46](1627)$ & $40.08[21.04](2133)$ & $n s^{h}$ \\
\hline EPICES score qualitative ${ }^{i}$ & $65.7(3791)$ & $66.7(1627)$ & $65.0(2133)$ & $n s^{h}$ \\
\hline Discrimination (yes) & $25.1(4120)$ & $25.1(1782)$ & $25.0(2314)$ & $n s^{h}$ \\
\hline Financial Social support (yes) & 79.0 (3379) & $78.7(1863)$ & $79.2(2377)$ & $n s^{h}$ \\
\hline Social worker support (yes) & $17.4(3991)$ & $16.6(1720)$ & $18.0(2247)$ & $n s^{h}$ \\
\hline Social network support (yes) & $38.5(4010)$ & $29.3(1723)$ & $45.4(2264)$ & $<0.001$ \\
\hline Family physician (yes) & $77.2(4248)$ & $69.1(1847)$ & $83.5(2364)$ & $<0.001$ \\
\hline Health care consumption (yes) & $33.9(4072)$ & $26.6(1755)$ & $39.3(2293)$ & $<0.001$ \\
\hline \multicolumn{5}{|l|}{ Health outcomes } \\
\hline Self-perceived health $(<7)$ & $26.7(4214)$ & $23.2(1835)$ & $29.6(2342)$ & $<0.001$ \\
\hline $\mathrm{MHI}-5^{f}(<56)$ & $38.2(4133)$ & $29.8(1786)$ & $44.9(2310)$ & $<0.001$ \\
\hline Suicide attempt (yes) & $14.7(4129)$ & $10.1(1783)$ & $18.2(2325)$ & $<0.001$ \\
\hline Tobacco smoke (yes) & $50.6(4243)$ & $58.4(1847)$ & $44.4(2360)$ & $<0.001$ \\
\hline Alcohol misuse $^{g}$ & $20.6(4049)$ & $29.8(1768)$ & $13.4(2246)$ & $<0.001$ \\
\hline Marijuana use & $20.4(4206)$ & $29.4(1833)$ & $13.4(2338)$ & $<0.001$ \\
\hline Victim of psychological violence (yes) & $34.2(4062)$ & $29.8(1760)$ & $37.5(2281)$ & $<0.001$ \\
\hline Victim of physical violence (yes) & $29.6(4036)$ & $31.4(1760)$ & $28.1(2253)$ & 0.03 \\
\hline Victim of sexual violence (yes) & $10.1(3988)$ & $3.4(1720)$ & $15.2(2247)$ & $<0.001$ \\
\hline
\end{tabular}

${ }^{a}$ percentage; ${ }^{b}$ mean; ${ }^{c}$ standard deviation; ${ }^{d}$ number of person with a response to the question; ${ }^{e}$ less than 2 nd school diploma; ${ }^{f}$ Mental Health Inventory; ${ }^{g} \geq 3$ drunkenness in the last year; ${ }^{h}$ ns: non statistically significant; i: EPICES score $>30.17=$ social deprivation 


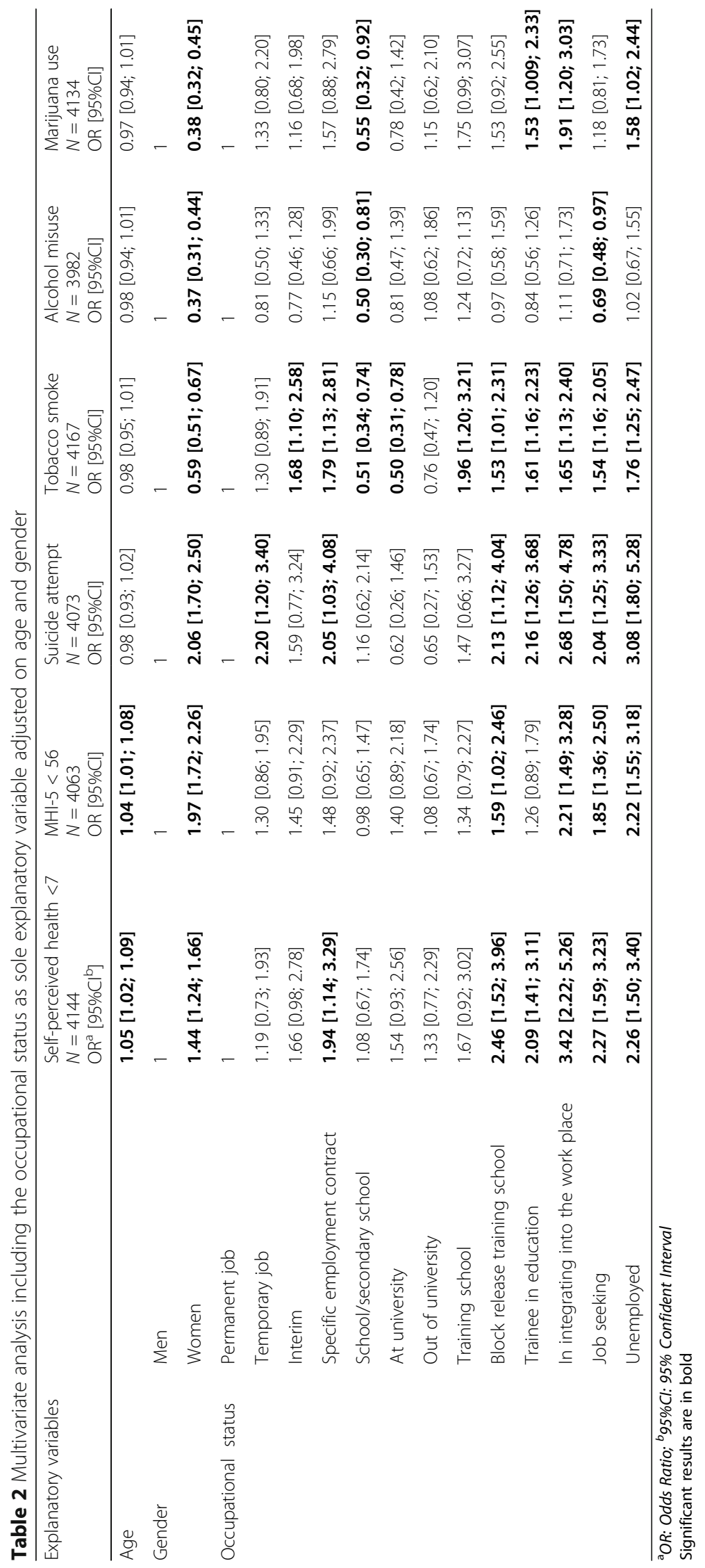


variables based on the calculation of the adjusted Odds Ratio (OR) and its 95\% Confidence Interval [95\%CI]. The $\mathrm{R}^{2}$ of Nagelkerke describing the appropriateness of fit of the model was presented. A meaningful threshold of $5 \%$ was chosen for all the statistical analyses. Statistical analysis was performed on SPSS V 16.0 software.

\section{Results}

A total of 4282 young people filled in the questionnaire, 1866 men and 2378 women, sex-ratio 0.79 and $8 \%$ refused to participate in (Table 1).

In the main four occupational statuses the young people included had, three were non-working statues, with in decreasing order: job seeker (36.3\%), trainee in work education (10.9\%), and to be unemployed (8.5\%). Occupational statuses were significantly different in men and women $(p<0.001)$ with higher percentage of men working in interim $(5.4 \%$ vs. $1.9 \%)$, being in training school (4.1\% vs. $1.4 \%)$, and undergoing integration into the work place $(7.1 \%$ vs. $4.5 \%)$ and lower percentage of men studying out of university (1.5\% vs. $4.2 \%)$. A total of $61.5 \%$ of the sample reported childhood life event. EPICES score mean was at 40.17 (standard deviation 20.34 ) and $79.0 \%$ declared having financial social support. A third of the sample (33.9\%) reported health care consumption with significant different behaviour by gender (men $26.6 \%$ vs women $39.3 \% ; p<0.001$ ) (Table 1 ).

Concerning global perception of health, $26.7 \%$ of young people included reported a poor self-perceived health, women in particular (men $23.2 \%$ vs. women 29.6 ; $p<0.001)$. Women experienced poor low mental health with higher percentage of young women in psychological distress (men $29.8 \%$ vs. women $44.9 \%, p<0.001$ ) and with medical history of suicide attempt (men $10.1 \%$ vs. women 18.2, $p<0.001$ ). Concerning addiction, half of the sample were current smokers (50.6\%), 20.6\% reported alcohol misuse with at least three drunkenness in the last year, and marijuana consumption with statistically significant difference by gender. Women reported higher exposition to psychological and sexual violence than men. On the contrary, men declared more physical violence than women (Table 1).

In the first step of the multivariate analysis, young people being unemployed, job seekers, undergoing integration into the work place, trainee in education and in block release training school, reported more adverse health outcomes than those working. They declared higher level of poor self-perceived health, more psychological distress, more suicide attempts, more tobacco and marijuana use and more violence irrespective of the type. In young people who worked, those in specific employment contract, declared poor self-perceived health more often, suicide attempts, tobacco use and reported being the victim of psychological violence more often than those who had permanent job. Young people at school or at secondary school were less addicted to tobacco, alcohol and marijuana than those who had permanent job (Tables 2 and 3).

In the last step of the multivariate analysis, occupational status remained as an explanatory variable for self-perceived health $\left(R^{2}=0.16\right)$ and addictions $\left(R^{2}\right.$

Table 3 Multivariate analysis including the occupational status as sole explanatory variable adjusted on age and gender

\begin{tabular}{|c|c|c|c|c|}
\hline \multicolumn{2}{|l|}{ Explanatory variables } & \multirow{2}{*}{$\begin{array}{l}\text { Victim of psychological violence } \\
N=4006 ; \mathrm{OR}^{\mathrm{a}}\left[95 \% \mathrm{Cl}^{\mathrm{b}}\right] \\
\mathbf{1 . 0 7}[\mathbf{1 . 0 3 ;} \mathbf{1 . 1 0}]\end{array}$} & \multirow{2}{*}{$\begin{array}{l}\text { Victim of physical violence } \\
N=3977 ; \text { OR }[95 \% \mathrm{Cl}] \\
\mathbf{1 . 0 3}[\mathbf{1 . 0 0 1} \mathbf{1 . 0 7 ]}\end{array}$} & \multirow{2}{*}{$\begin{array}{l}\text { Victim of sexual violence } \\
N=3935 ; \text { OR }[95 \% \mathrm{Cl}] \\
\mathbf{1 . 0 8}[\mathbf{1 . 0 3} ; \mathbf{1 . 1 3}]\end{array}$} \\
\hline Age & & & & \\
\hline \multirow[t]{2}{*}{ Gender } & Men & 1 & 1 & 1 \\
\hline & Women & $1.44[1.25 ; 1.65]$ & $0.88[0.76 ; 1.02]$ & $5.27[3.94 ; 7.04]$ \\
\hline \multirow[t]{13}{*}{ Occupational status } & Permanent job & 1 & 1 & 1 \\
\hline & Temporary job & $1.39[0.91 ; 2.11]$ & $1.08[0.69 ; 1.69]$ & $0.94[0.44 ; 1.99]$ \\
\hline & Interim & $1.82[1.15 ; 2.87]$ & $1.52[0.95 ; 2.44]$ & $1.70[0.74 ; 3.89]$ \\
\hline & Specific employment contract & $1.84[1.13 ; 2.96]$ & $1.40[0.84 ; 2.31]$ & $1.33[0.59 ; 2.95]$ \\
\hline & School/secondary school & $1.39[0.92 ; 2.10]$ & $1.15[0.75 ; 1.76]$ & $1.56[0.78 ; 3.11]$ \\
\hline & At university & $1.30[0.82 ; 2.07]$ & $0.70[0.41 ; 1.20]$ & $1.17[0.52 ; 2.60]$ \\
\hline & Out of university & $1.12[0.68 ; 1.85]$ & $0.77[0.44 ; 1.35]$ & $0.62[0.23 ; 1.62]$ \\
\hline & Training school & $1.25[0.72 ; 2.17]$ & $1.07[0.61 ; 1.88]$ & $1.10[0.34 ; 3.45]$ \\
\hline & Block release training school & $1.79[1.14 ; 2.80]$ & $1.84[1.16 ; 2.89]$ & $1.18[0.52 ; 2.69]$ \\
\hline & Trainee in education & $1.94[1.36 ; 2.77]$ & $1.59[1.10 ; 2.30]$ & $1.88[1.04 ; 3.39]$ \\
\hline & In integrating into the work place & $2.56[1.72 ; 3.81]$ & $2.00[1.32 ; 3.00]$ & $2.83[1.48 ; 5.41]$ \\
\hline & Job seeking & $1.71[1.25 ; 2.33]$ & $1.54[1.12 ; 2.13]$ & $1.87[1.10 ; 3.16]$ \\
\hline & Unemployed & $1.88[1.30 ; 2.73]$ & $1.69[1.15 ; 2.47]$ & $3.13[1.74 ; 5.61]$ \\
\hline
\end{tabular}


from 0.10 to 0.13$)$. Poor self-perceived health was reported by young people in block release training school $(\mathrm{OR}=1.76$; 95\%CI $[1.01 ; 3.06])$, and undergoing integration into the work place $(\mathrm{OR}=1.99$; $95 \%$ CI $[1.21 ; 3.24]$ ) more often. Young people in training school were more exposed to tobacco $(\mathrm{OR}=2.25 ; 95 \% \mathrm{CI}[1.29 ; 3.93])$ and marijuana use $(\mathrm{OR}=2.12 ; 95 \% \mathrm{CI}[1.15 ; 3.89])$. Young people at school and secondary school remained less exposed to addiction (tobacco smoke: $\mathrm{OR}=0.53 ; 95 \% \mathrm{CI}[0.34$; 0.81 ], and alcohol misuse $\mathrm{OR}=0.57 ; 95 \% \mathrm{CI}[0.34 ; 0.95]$ ). The main explanatory variables frequently associated to the other health outcomes were gender (female),major event in childhood, discrimination, being deprived, and higher needs of social worker support, social network support and health care consumption (Tables 4 and 5).

\section{Discussion \\ Main results}

Occupational status of French young people was a determinant of poorer self-perceived health, addictions and mental health. Young French people who were either not at work, at work without a permanent status or studying in training school or block release training school, were more exposed to poor mental health outcomes.

It is also interesting to point out that to add the measurement of individual social deprivation through the

Table 4 Multivariate analysis including all explanatory variables for self-perceived health and addictions adjusted on age and gender

\begin{tabular}{|c|c|c|c|c|c|}
\hline \multicolumn{2}{|l|}{ Explanatory variables } & \multirow{2}{*}{$\begin{array}{l}\text { Self-perceived health }<7 \\
N=3500 ; R^{2 a}=0.16 \\
\operatorname{OR}^{b}[95 \% \mathrm{Cl}]^{c} \\
1.03[0.99 ; 1.07]\end{array}$} & \multirow{2}{*}{$\begin{array}{l}\text { Tobacco smoke } \\
N=3480 ; R^{2}=0.13 \\
\text { OR }[95 \% \mathrm{Cl}] \\
1.02[0.98 ; 1.06]\end{array}$} & \multirow{2}{*}{$\begin{array}{l}\text { Alcohol misuse } \\
N=3723 ; R^{2}=0.10 \\
\text { OR }[95 \% \mathrm{Cl}] \\
0.93[0.92 ; 1.01]\end{array}$} & \multirow{2}{*}{$\begin{array}{l}\text { Marijuana use } \\
N=3498 ; R^{2}=0.13 \\
\text { OR }[95 \% \mathrm{CI}] \\
0.98[0.94 ; 1.03]\end{array}$} \\
\hline Age & & & & & \\
\hline \multirow[t]{2}{*}{ Gender } & Men & 1 & 1 & 1 & 1 \\
\hline & Women & $1.36[1.14 ; 1.61]$ & $0.59[0.50 ; 0.68]$ & $0.34[0.28 ; 0.40]$ & $0.34[0.28 ; 0.41]$ \\
\hline \multirow[t]{13}{*}{ Occupational status } & Permanent job & 1 & 1 & 1 & 1 \\
\hline & Temporary job & $0.81[0.46 ; 1.41]$ & $1.18[0.77 ; 1.79]$ & $0.80[0.48 ; 1.32]$ & $1.13[0.65 ; 1.96]$ \\
\hline & Interim & $1.01[0.55 ; 1.85]$ & $1.31[0.82 ; 2.10]$ & $0.74[0.43 ; 1.28]$ & $0.95[0.53 ; 1.69]$ \\
\hline & Specific employment contract & $1.07[0.57 ; 1.96]$ & $1.36[0.82 ; 2.24]$ & $1.08[0.61 ; 1.90]$ & $1.25[0.66 ; 2.33]$ \\
\hline & School/secondary school & $0.90[0.52 ; 1.55]$ & $0.53[0.34 ; 0.81]$ & $0.57[0.34 ; 0.95]$ & $0.64[0.36 ; 1.12]$ \\
\hline & At university & $1.59[0.91 ; 2.79]$ & $0.59[0.36 ; 0.97]$ & $0.59[0.33 ; 1.05]$ & $0.68[0.35 ; 1.32]$ \\
\hline & Out of university & $1.42[0.78 ; 2.58]$ & $0.96[0.59 ; 1.58]$ & $0.90[0.51 ; 1.59]$ & $1.23[0.65 ; 2.34]$ \\
\hline & Training school & $1.67[0.86 ; 3.25]$ & $2.25[1.29 ; 3.93]$ & $1.44[0.82 ; 2.53]$ & $2.12[1.15 ; 3.89]$ \\
\hline & Block release training school & $1.76[1.01 ; 3.06]$ & $1.27[0.80 ; 2.01]$ & $1.11[0.66 ; 1.87]$ & $1.68[0.96 ; 2.91]$ \\
\hline & Trainee in education & $1.29[0.82 ; 2.03]$ & $1.31[0.91 ; 1.88]$ & $0.89[0.58 ; 1.35]$ & $1.33[0.84 ; 2.11]$ \\
\hline & In integrating into the work place & $1.99[1.21 ; 3.24]$ & $1.47[0.97 ; 2.24]$ & $1.24[0.78 ; 1.96]$ & $1.54[0.93 ; 2.55]$ \\
\hline & Job seeking & $1.45[0.97 ; 2.17]$ & $1.30[0.95 ; 1.78]$ & $0.72[0.50 ; 1.03]$ & $1.00[0.66 ; 1.50]$ \\
\hline & Unemployed & $1.21[0.75 ; 1.94]$ & $1.36[0.92 ; 2.00]$ & $1.11[0.72 ; 1.72]$ & $1.37[0.84 ; 2.21]$ \\
\hline \multirow[t]{2}{*}{ Level of education } & $>$ 2nd school diploma & & 1 & 1 & \\
\hline & $<2$ nd school diploma & & $1.53[1.28 ; 1.82]$ & $0.63[0.51 ; 0.78]$ & \\
\hline \multirow[t]{2}{*}{ Major event in childhood } & No & 1 & 1 & 1 & 1 \\
\hline & Yes & $1.31[1.10 ; 1.57]$ & $1.81[1.55 ; 2.10]$ & $1.42[1.18 ; 1.70]$ & $1.87[1.53 ; 2.27]$ \\
\hline \multirow[t]{2}{*}{ Social network support } & No & & 1 & 1 & 1 \\
\hline & Yes & & $1.36[1.16 ; 1.58]$ & $1.55[1.30 ; 1.85]$ & $1.59[1.32 ; 1.90]$ \\
\hline \multirow[t]{2}{*}{ Discrimination } & No & 1 & 1 & & \\
\hline & Yes & $1.46[1.22 ; 1.75]$ & $0.71[0.60 ; 0.85]$ & & \\
\hline EPICES score & & $1.02[1.01 ; 1.03]$ & $1.01[1.005 ; 1.02]$ & & $1.01[1.005 ; 1.02]$ \\
\hline \multirow[t]{2}{*}{ Social worker support } & No & & & & \\
\hline & Yes & $1.33[1.07 ; 1.66]$ & & & \\
\hline \multirow[t]{2}{*}{ Health care consumption } & No & 1 & & & \\
\hline & Yes & $1.89[1.57 ; 2.26]$ & & & \\
\hline
\end{tabular}

${ }^{a} R^{2}: R^{2}$ de Nagelkerke ${ }^{b}$ OR: Odds Ratio; ${ }^{c} 95 \%$ Cl: $95 \%$ Confident Interval Significant results are in bold 
Table 5 Multivariate analysis including all explanatory variables for mental health and violence adjusted on age and gender

\begin{tabular}{|c|c|c|c|c|c|c|}
\hline Explanatory variables & & $\begin{array}{l}\mathrm{MHI}-5<56 \\
N=3496 \\
\mathrm{R}^{2 a}=0.26 \\
\mathrm{OR}^{b}[95 \% \mathrm{Cl}]^{c}\end{array}$ & $\begin{array}{l}\text { Suicide attempt } \\
N=3451 \\
R^{2}=0.22 \\
\text { OR }[95 \% \text { Cl] }\end{array}$ & $\begin{array}{l}\text { Victim of } \\
\text { psychological violence } \\
N=3473 ; R^{2}=0.25 \\
\mathrm{OR}^{\mathrm{a}}\left[95 \% \mathrm{Cl}^{\mathrm{b}}\right]\end{array}$ & $\begin{array}{l}\text { Victim of } \\
\text { physical violence } \\
N=3405 ; R^{2}=0.19 \\
\text { OR }[95 \% \text { Cl] }\end{array}$ & $\begin{array}{l}\text { Victim of } \\
\text { sexual violence } \\
N=3424 ; R^{2}=0.20 \\
\text { OR }[95 \% \text { Cl] }\end{array}$ \\
\hline Age & & $1.02[0.98 ; 1.05]$ & $0.97[0.92 ; 1.01]$ & 1.04 [1.007; 1.08] & $1.02[0.98 ; 1.06]$ & $1.04[0.98 ; 1.09]$ \\
\hline \multirow[t]{2}{*}{ Sex } & Men & 1 & 1 & 1 & 1 & 1 \\
\hline & Women & $1.81[1.54 ; 2.12]$ & $1.89[1.51 ; 2.37]$ & $1.19[1.01 ; 1.40]$ & $0.76[0.64 ; 0.90]$ & $4.75[3.44 ; 6.56]$ \\
\hline \multirow[t]{2}{*}{ Level of education } & $\begin{array}{l}>\text { 2nd school } \\
\text { diploma }\end{array}$ & & 1 & & 1 & \\
\hline & $\begin{array}{l}<\text { 2nd school } \\
\text { diploma }\end{array}$ & & $1.46[1.12 ; 1.88]$ & & $1.37[1.13 ; 1.67]$ & \\
\hline \multirow[t]{2}{*}{ Major event in childhood } & No & 1 & 1 & 1 & 1 & 1 \\
\hline & Yes & $1.34[1.13 ; 1.58]$ & $1.82[1.42 ; 2.34]$ & $1.89[1.58 ; 2.34]$ & $1.89[1.57 ; 2.26]$ & $2.23[1.64 ; 3.02]$ \\
\hline \multirow[t]{2}{*}{ Social network support } & No & 1 & 1 & 1 & 1 & 1 \\
\hline & Yes & $2.11[1.79 ; 2.49]$ & $1.79[1.43 ; 2.24]$ & $3.13[2.64 ; 3.70]$ & $2.05[1.72 ; 2.45]$ & $1.61[1.24 ; 2.09]$ \\
\hline \multirow[t]{2}{*}{ Discrimination } & No & 1 & 1 & 1 & 1 & 1 \\
\hline & Yes & $1.72[1.44 ; 2.06]$ & $1.36[1.08 ; 1.70]$ & $1.66[1.38 ; 1.98]$ & $1.53[1.28 ; 1.84]$ & $1.48[1.14 ; 1.92]$ \\
\hline EPICES score & & $1.03[1.02 ; 1.04]$ & $1.02[1.01 ; 1.03]$ & $1.02[1.01 ; 1.03]$ & $1.02[1.01 ; 1.03]$ & $1.02[1.01 ; 1.03]$ \\
\hline \multirow[t]{2}{*}{ Social worker support } & No & & & 1 & 1 & 1 \\
\hline & Yes & & $1.40[1.08 ; 1.80]$ & $1.29[1.03 ; 1.61]$ & $1.53[1.23 ; 1.91]$ & $1.46[1.08 ; 1.97]$ \\
\hline \multirow[t]{2}{*}{ Health care consumption } & No & 1 & 1 & 1 & 1 & 1 \\
\hline & Yes & $2.08[1.75 ; 2.46]$ & $2.33[1.85 ; 2.92]$ & $1.59[1.33 ; 1.90]$ & $1.39[1.15 ; 1.68]$ & $1.56[1.18 ; 2.04]$ \\
\hline
\end{tabular}

${ }^{\mathrm{a}} R^{2}: R^{2}$ de Nagelkerke ${ }^{b}$ OR: Odds Ratio; ${ }^{c} 95 \% \mathrm{Cl}: 95 \%$ Confident Interval

Significant results are in bold

EPICES score into the multivariate analysis undermined occupational status and especially the non-working categories. Non-working status categories therefore seemed measuring individual social deprivation too. On the other hand, greater odds ratio was observed for the category "training school" when EPICES score was added, for consumption of tobacco and marijuana.

Concerning addiction, the protective association of school, secondary school and university, was another point of interest. Indeed, to study at university was not protective for alcohol consumption revealing the impact of binge drinking. Non-working occupational status was not associated with higher alcohol misuse but on the contrary to lower alcohol misuse, job seeking in particular, which means that alcohol misuse seemed to be more significant into social groups.

\section{Comparisons with other studies}

Non-working status categories were identified as a variable measuring individual social deprivation. This result was support by Benach et al. who explained in their work: "precarious employment is clearly related to absolute and relative social deprivation" [16].

Virtanen et al. revealed that unemployed included three categories; compensation-income, subsidy or low-income, expressed systematically poor self-rate health irrespective of the gender, which mirrors our findings [26]. This conclusion was also drawn for atypical employees defining by all form of work excepted permanent employees and fixed-term employees, as in our survey for young people being in interim or with a specific employment contract. Virtanen et al. deepened their results in a review, revealing an association between temporary employment and increased psychological morbidity [9]. László et al. showed an association between job insecurity and health in European countries, even though it was not significant in France [7]. Bambra et al. provided further evidence of such an association in the 2010 European Working Conditions Survey [8]. Employees having a temporary contract reported significant poor self-perceived health $(\mathrm{OR}=1.24$; 95\%CI [1.13-1.37]). Two recent Italian studies also identified that people in unstable working conditions declared poorer self-perceived health than permanent workers [6, 27]. One of the studies revealed that this association existed among young people in particular [27]. Three previous French studies showed association between employment characteristics, full time vs. part time and permanent job vs. non-permanent job and adverse health outcomes like self-perceived health [28-30]. When comparing genders, studies identified that both men and women expressed more damage on heath when they are in unstable working conditions. Nonetheless, while one study argues that men are more unhealthy than women, most of the studies showed higher vulnerability in women as revealed in our study [12, 27, 31]. 


\section{Implication for the future}

To tackle health inequities among young people belonging to a non-working status category was complicated. Indeed, as previously demonstrated by the WHO into the micro-conceptual framework and Benach et al. through their conceptual model putting precarious employment as a central issue, several factors should be considered simultaneously by policies, which makes these policies harder to be effective $[3,16]$.

On the other hand, to base strategies on the reinforcement of the protective effect of education appeared to be relevant. It was especially the case for alcohol consumption for which the protective effect seemed to be lower at university. Prevention policies should also take into consideration that young people in training school did not have the same protective effect as secondary school and university, for tobacco and marijuana consumption, in particular.

Individual life trajectories, including major event during childhood seemed to be a significant point to consider.

\section{Strength and limitation}

The present work was a multicentre survey (115 LSC and 74 HEC) with a large sample (4282) of French young people. To our knowledge, this study was the sole which targeted young people in LSC. Occupational status was detailed in 13 categories but working conditions were not explored preventing us to assess deeply potential association between health outcomes and job characteristics such as number of hours worked per day, flexible employment, and if non-permanent job corresponds in personal choice or not. Individual employment trajectories, such as work linked to study field, type of work performed, were also not assessed accurately. Individual life trajectories were approached by the measurement of event during childhood. Furthermore, as young people who participated were volunteers, those in the worst life and health conditions could be not included.

\section{Conclusions}

Occupational status of French young people was a determinant of health inequities. Young people in block release training school, training in education, undergoing integration into the work place, and job seeking, reported greater vulnerability to poor-self perceived health, addictions, poor mental health and violence. Young French people in training school or in block release training school do not benefit from occupational medicine service or university medicine service. This population should therefore be targeted by appropriate and specific social and medical services.

\section{Additional files}

Additional file 1: Definitions about working according French rules. (PDF $66 \mathrm{~kb}$ )

Additional file 2: Questionnaire. (PDF $243 \mathrm{~kb}$ )

\section{Abbreviations}

95\%Cl: 95\% Confidence Interval; ADRS: Adolescent Depression Rating Scale; CETAF: Education Technical Centre of Health Examination Centres (Centre technique d'appui et de formation des centres d'examens de santé); CNAMts: the French national health insurance for salaried workers (Caisse Nationale d'Assurance Maladie-travailleurs salariés); CNML: National Council of Local Social Centres (Conseil National des Missions Locales-; DGAS: Social Welfare Directorate (Direction Générale de I'Action Sociale); DGS: Health Directorate (Direction Générale de la Santé); ESPAD: European School Survey Project on Alcohol and Other Drugs; HEC: Health Examination Centres; ILO: International Labour Organization; Insee: National Institute of Statistics and Economic studies; LSC: Local Social Centres; MHI-5: Mental Health Index-5 items; OFDT: French Monitoring Centre for Drugs and Drug Addiction (Observatoire Français des drogues et des Toxicomanies); OR: Odds Ratio Support); WHO: World Health Organization-Europe

\section{Acknowledgments}

We thank the National Council of Local Social Centres (Conseil National des Missions Locales- CNML) and Pierrette Catel, in particular. We thank all Local Social Centres and Health Examination Centres who participate in. In memory of Dr. Pascal Courty.

\section{Funding}

This work was funded by the support and education technic centre of health examination centres (CETAF: Centre technique d'appui et de formation des centres d'examens de santé) and the National Council of Local Social Centres (Conseil National des Missions Locales- CNML).

Availability of data and materials

Please contact author for data requests.

Authors' contributions

$E L L, C S, D B$ and $L G$ elaborated the protocol of the survey. ELL performed the statistical analysis. MB, ELL and LG interpreted the results. MB, ELL, CS, DB and

LG wrote the article. All authors read and approved the final manuscript.

Ethics approval and consent to participate

Anonymous data were recorded according to CNIL guidelines (National Ethics Committee when computerized data are used).

Consent for publication

All authors named have full control of the content of the article.

Competing interests

The authors declare that they have no competing interests.

\section{Publisher's Note}

Springer Nature remains neutral with regard to jurisdictional claims in published maps and institutional affiliations.

\section{Author details}

${ }^{1}$ Service de Santé Publique, Centre Hospitalier Universitaire de Clermont-Ferrand, 7, place Henri Dunant CEDEX 1, 63058 Clermont-Ferrand, France. ${ }^{2}$ Clermont Université, Université d'Auvergne, EA 4681, PEPRADE (Périnatalité, grossesse, Environnement, PRAtiques médicales et DEveloppement), Clermont-Ferrand, France. ${ }^{3}$ Centre Technique d'Appui et de Formation des Centres d'Examens de Santé, Cetaf, 67/69 Avenue de Rochetaillée, 42100 Saint-Etienne, France. ${ }^{4}$ Université Claude Bernard Lyon 1 - ESPE, Université de Lyon, HESPER - Health Services and Performance Research, 5 rue Anselme, Cedex, 69004 Lyon, France. 
Received: 13 March 2017 Accepted: 24 July 2017

Published online: 08 August 2017

\section{References}

1. Dahlgren $G$, Whitehead M. European strategies for tackling social inequities in health. World Health Organization. 2007. http://www.euro.who.int/_data/assets/ pdf_file/0018/103824/E89384.pdf.

2. Benach Joan, Muntaner Carles, Santana Vilma. Employment Conditions and Health Inequalities. World Health Organization; p. 172. http://mww.icariaeditorial.com/ pdf_libros/Employmentweb_low.pdf.

3. Lee, Jennifer H, Sadana Ritu. Improving Equity in Health by adressing Social Determinants. World Health Organization; p. 319. http://apps.who.int/iris/ handle/10665/44793.

4. Karmakar SD, Breslin FC. The role of educational level and job characteristics on the health of young adults. Soc Sci Med 1982. 2008;66:2011-22.

5. Hämmig O, Bauer GF. The social gradient in work and health: a cross-sectional study exploring the relationship between working conditions and health inequalities. BMC Public Health. 2013;13:1170.

6. Pirani E, Salvini S. Is temporary employment damaging to health? A longitudinal study on Italian workers. Soc Sci Med 1982. 2015;124:121-31.

7. László KD, Pikhart H, Kopp MS, Bobak M, Pajak A, Malyutina S, et al. Job insecurity and health: a study of 16 European countries. Soc Sci Med 1982. 2010;70:867-74.

8. Bambra C, Lunau T, Wel KAV der, Eikemo TA, Dragano N. Work, health, and welfare: the association between working conditions, welfare states, and self-reported general health in Europe. Int J Health Serv 2014;44:113-136.

9. Virtanen $M$, Kivimäki $M$, Joensuu $M$, Virtanen $P$, Elovainio M, Vahtera J. Temporary employment and health: a review. Int J Epidemiol. 2005;34:610-22.

10. Sultan-Taïeb H, Chastang J-F, Mansouri M, Niedhammer I. The annual costs of cardiovascular diseases and mental disorders attributable to job strain in France. BMC Public Health. 2013;13:748.

11. Joyce K, Pabayo R, Critchley JA, Bambra C. Flexible working conditions and their effects on employee health and wellbeing. Cochrane Database Syst. Rev. John Wiley \& Sons, Ltd; 2010 [cité 3 sept 2015]. Disponible sur: http:// onlinelibrary.wiley.com/doi/10.1002/14651858.CD008009.pub2/abstract

12. De Moortel D, Vandenheede H, Vanroelen C. Contemporary employment arrangements and mental well-being in men and women across Europe: a cross-sectional study. Int. J. Equity Health. 2014 [cité 3 sept 2015];13. Disponible sur: http://www.ncbi.nlm.nih.gov/pmc/articles/PMC4219120/

13. Slany C, Schütte S, Chastang J-F, Parent-Thirion A, Vermeylen G, Niedhammer I. Psychosocial work factors and long sickness absence in Europe. Int J Occup Environ Health. 2014;20:16-25.

14. Wresinski J. Grande pauvreté et précarité économique et sociale. Conseil économique et social; 1987 févr p. 113. http://www.joseph-wresinski.org/ fr/grande-pauvrete-et-precarite/.

15. Townsend P. Deprivation. J Soc Policy. 1987;16:125-46.

16. Benach J, Vives A, Amable M, Vanroelen C, Tarafa G, Muntaner C. Precarious employment: understanding an emerging social determinant of health. Annu Rev Public Health. 2014;35:229-53.

17. Guggemos F, Vidalenc J. Une photographie du marché du travail en 2013. Insee Prem. 2014; https://www.insee.fr/fr/statistiques/1560271.

18. Arrêté du 20 juillet 1992 relatif aux examens périodiques de santé. https://www.legifrance.gouv.fr/affichTexte.do?cidTexte=LEGITEXT000006079995.

19. Labbe E, Blanquet M, Gerbaud L, Poirier G, Sass C, Vendittelli F, et al. A new reliable index to measure individual deprivation: the EPICES score. Eur J Pub Health. 2015;25:604-9.

20. Sass C, Moulin J, Guéguen R, Abric L, Dauphinot V, Dupré C, et al. Le score Epices: un score individuel de précarité. Construction du score et mesure des relations avec des données de santé, dans une population de 197389 personnes. Bull. Epidémiologique Hebd. 2006;93-6.

21. Revah-Levy A, Birmaher B, Gasquet I, Falissard B. The adolescent depression rating scale (ADRS): a validation study. BMC Psychiatry. 2007;7:2.

22. Idler EL, Benyamini Y. Self-rated health and mortality: a review of twenty-seven community studies. J Health Soc Behav. 1997;38:21-37.

23. Manderbacka K. Examining what self-rated health question is understood to mean by respondents. Scand J Soc Med. 1998;26:145-53.

24. Beaud B, Fournier B, Aubry C, Henry J. Santé perçue et grossesse : Etude de quelques déterminants comportementaux et environnementaux dans une population de femmes enceintes. Santé Publique. 1998;10:49-70.
25. Royer B, Gusto G, Vol S, D’Hour A, Arondel D, Tichet J, et al. Situations de précarité, santé perçue et troubles anxiodépressifs : une étude dans 12 centres d'examens de santé. Prat Organ Soins. 2010;41:313-21.

26. Virtanen $\mathrm{P}$, Liukkonen $\mathrm{V}$, Vahtera J, Kivimäki M, Koskenvuo $\mathrm{M}$. Health inequalities in the workforce: the labour market core-periphery structure. Int J Epidemiol. 2003;32:1015-21.

27. Minelli L, Pigini C, Chiavarini M, Bartolucci F. Employment status and perceived health condition: Iongitudinal data from Italy. BMC Public Health [Internet]. 2014 [cité 4 sept 2015];14. Disponible sur: http://www. ncbi.nlm.nih.gov/pmc/articles/PMC4177701/

28. Labbe E, Moulin J, Sass C, Chatain C, Guéguen R, Gerbaud L. Health status, behaviours and social environment in a population of 105901 young people involved in short training courses. Prat Organ Soins. 2007;38:43-53.

29. Moulin J, Labbe E, Sass C, Gerbaud L. Job insecurity, unemployment and health: results from the health examination centers of the French general health insurance. Rev DÉpidémiologie Santé Publique. 2009;57:141-9.

30. Labbe E, Moulin J, Sass C, Chatain C, Gerbaud L. Relations entre formes particulières d'emploi, vulnérabilité sociale et santé. Arch Mal Prof Environ. 2007;68:365-75.

31. Campos-Serna J, Ronda-Pérez E, Artazcoz L, Moen BE, Benavides FG. Gender inequalities in occupational health related to the unequal distribution of working and employment conditions: a systematic review. Int J Equity Health. 2013;12:57.

\section{Submit your next manuscript to BioMed Central and we will help you at every step:}

- We accept pre-submission inquiries

- Our selector tool helps you to find the most relevant journal

- We provide round the clock customer support

- Convenient online submission

- Thorough peer review

- Inclusion in PubMed and all major indexing services

- Maximum visibility for your research

Submit your manuscript at www.biomedcentral.com/submit
C Biomed Central 